\title{
A REVIEW AND CRITIQUE OF HYBRID MADM METHODS APPLICATION IN REAL BUSINESS
}

\author{
Jiri Franek \\ Faculty of Economics \\ VSB-Technical University of Ostrava \\ Ostrava, Czech Republic \\ E-mail: jiri.franek@vsb.cz \\ Katerina Kashi \\ Faculty of Economics \\ VSB-Technical University of Ostrava \\ Ostrava, Czech Republic \\ E-mail: katerina.kashi@vsb.cz
}

\begin{abstract}
Since its introduction the MADM techniques had witnessed a great development and popularity among scholars. Their application range from very basic towards more sophisticated using MOLP and fuzzy operations. However, many scholars and authors have researched various possibilities of MADM practical use but it seems the real business hasn't caught up with the same enthusiasm. Hierarchical and network thinking is very important for any strategists and entrepreneurs. Nevertheless, contemporary attitude towards decision making is not in favor of rigorous process. The most frequent plea is that the speed and efficiency should prevail when the real business environment is much more dynamic and turbulent. So entrepreneurs and managers have difficulties in filling in the questionnaires for comparing the criteria and alternatives. The lack of agreement in the criterion evaluation and compromise thus limits the application of MADM techniques. Another problem is associated with a large number of evaluation criteria that is often needed and the network of interdependencies. This paper deals with a review of applications that can be considered as useful in real business and based on empirical research proposes a suggestion of specific tasks that could be used and accepted in real business. The paper consists of summary of relevant literature then follows short description of applied methods, description and results of empirical research and concludes with proposal of several business tasks that could be facilitated by selected MADM methods.
\end{abstract}

Keywords: AHP, ANP, DEMATEL, TOPSIS, VIKOR, decision making, management 


\section{Introduction}

Business environment is experiencing a period of development of the knowledge society that has influenced decision making processes of firms, organizations and individuals. However many important strategic decisions are made on the basis of self evidence, intuition and not always fully comprehend relationships among evaluated factors.

Decision making is important and no less difficult part of business economics. When the decision making problem occurs there is usually a limited number of possible alternatives but a large number of criteria according to which the optimal solution is selected. The multiple criteria decision-making (MCDM) methods have been successfully applied to many business and management decision making problems. Set of MCDM methods can be divided into two main streams: the multiple attribute decision making (MADM) methods with finite number of alternatives and mathematical optimization linear programming (MOLP). In this case we concentrate on the MADM methods that are more convenient for use in decision making problems within the business domain. The MADM methods are well developed and have a strong mathematical basis.

Though, several software solutions are available, they are not among business tools used on daily basis. Non-expert users who deal with relatively complex but straight forward decision making problems should be able to use them more often. When determining the significance of a particular pair of criteria for the object investigated, an expert should mentally 'weigh' the respective importance of other pairs of the criteria considered. When the number of criteria is large, it is a challenging problem. Practical application of MADM methods has revealed that only a few experts could avoid contradictions in filling out questionnaires (matrices), on which MADM approach is based. Transitivity of the evaluation criteria is often violated, thus demonstrating the limitations of these methods.

The aim of this paper is to investigate how MADM methods should be applied and presented to non-expert users in real business. The research approach consists of case studies that try to reveal convenient approaches to MADM method's practical use.

\section{Literature Review}

In recent years there has been a shift towards more sophisticated use of decision support tools and methods. Unfortunately their implementation is still not widespread among small and medium-sized companies. There is no need for them to purchase expensive software or implement sophisticated decision support processes but just understand some basic decision-making methods that can help to make their work more effective. Among the most widely discussed MADM methods Analytic Hierarchy Process (AHP) and Analytic Network Process (ANP) can be identified. These methods represent a group of decomposition multiple attribute decision-making approaches that were developed by Saaty $(1977,1996)$ respectively. Decision Making Trial and Evaluation Laboratory (DEMATEL) has been developed to construct the interrelations between factors/criteria to build the impact of a network relation map (Tzeng and Huang, 2011). These methods are specifically designed for complex decision making problems with network or hierarchical structure. Other scholars have concentrated their efforts on methods that can deal with larger numbers of criteria and alternatives. The Technique for Order Preferences by Similarity to an Ideal Solution (TOPSIS) method was proposed by Hwang 
and Yoon (1981). The compromise solution can be regarded as choosing the solution with the shortest Euclidean distance from the ideal solution and the farthest Euclidean distance from the negative ideal solution. "Vlse Kriterijumska Optimizacija I Kompromisno Resenje" (VIKOR) method was developed for multiple criteria optimization of complex systems (Tzeng and Huang, 2011).

\section{Objectives}

The goal of this paper is to present advantages, disadvantages and practical application of MADM methods in a real business within following framework.

\subsection{MADM methods with pair-wise comparisons}

What support should managers expect from MADM? At the very least, it should order decision making process and evaluation of factors in a way that allows them to provide transparent and more reliable solutions. In this case pair-wise comparison can serve as a tool and is base for AHP, ANP and DEMATEL methods. The user has to break down difficult and complex decisions into small judgments. However, when the number of comparisons is large, it is very time consuming to provide pair-wise judgments for all combinations. This discourages most of managers. In the period when there is a shortage of resources and time they are not willing to accept further difficulty. The aim is to convince them of MADM advantages and counteract against the shortcomings.

\subsection{MADM methods using compromise solution for ranking of alternatives}

When there is a need for relatively quick ranking and ordering of items decision makers can rely on TOPSIS and VIKOR. The main advantage of this approach is that its user could directly input judgment data without any previous mathematical calculations and make a list of alternatives that share similar properties. The VIKOR method is best for ranking and selecting from a set of alternatives in case of conflicting criteria. Both methods can be combined with decomposition methods of AHP/ANP and DEMATEL. The aim is to find characteristic applications for such hybrid methods.

\subsection{Collaborative decision making and group decision making}

AHP/ANP and DEMATEL are widely used in the area of collaborative decision making. The aim would be to generalize such a process in a real business and within a real organizational structure.

\subsection{Further combinations of MADM methods}

The list of combinations could be large. However, one interesting methodological approach seems to standing out. Recent studies and application of Data Envelopment Analysis show that this method could be combined with AHP/ANP methods as well.

\section{Research Design}

The research design consists of case studies and a proposal of most convenient approach to MADM method's practical use. The research consists of following steps:

- summarization of MAMD methods into practical manuals;

- presentation of decision making methods to entrepreneurs and managers;

- discussion and feedback evaluation of presented methodology; 
- case studies in real business situations and evaluation the procedures;

- assessment of case studies;

- proposal of model MADM applications that can be used by non-expert users.

The research will use the means of qualitative research tools such as structured interviews and feedback sessions.

\section{Data/Model Analysis}

Data are collected from three main sources:

- secondary data in the form of review of previous studies concerned with MADM application in business and management,

- own case studies that were executed by authors and their collaborators,

- primary data from interviews and feedback.

\section{Limitations}

The limitation of the study can be found in its longevity and scope. Researchers are using business contact network that helps to find interested business practitioners. However, so far the response was low. This barrier is counterbalanced by lectures given to larger business audience within the university business courses. After short tutorial managers should be able to use model tools and apply it on ordinary decision-making tasks. Less complicated cases can be solved quickly using Excel sheets with AHP tables.

\section{Conclusions}

The strategic thinker or line manager need information and also have to have a tool which can use it for evaluation of particular situation or decision making. Both external and internal factors have to be considered but they also exist in a form of qualitative or quantitative information. MADM methods can be used as tools which can cope with them. Furthermore they can prioritize these factors and based on the also select a group of most favorable alternatives. One of the most prominent features of MAMD methodology is to evaluate quantitative as well as qualitative criteria and alternatives on the same preference scale. These can be numerical, verbal or graphical. The use of verbal responses is intuitive. It may also allow some ambiguity in non-trivial comparisons. Due to it's pair-wise comparisons AHP/ANP and DEMATEL needs ratio scales. There are some disputes about scale as the best option of judgment expression but most scholars still prefer this approach. Further note should be given on consistency. The concept of AHP/ANP pair-wise comparisons is inseparable from consistency checking. Often the evaluators are not familiar with AHP. They will need to understand how the inconsistency translates in to their decision making process. There might be some comparisons that are not just inconsistent, but are downright contradictory. In most cases, these are errors that have to be fixed but are very hard to find without full understanding of the method.

MADM methods can also serve as a basis for more transparent and traceable decision making. The fundamental advantages of multi-criteria decision making methods can be found in the decision maker's ability to evaluate each alternative using a large number of criteria. These methods compel the decision maker to express explicitly (not intuitively) its understanding towards the importance of each criteria. Thus the whole process of 
ISAHP Article: Franek, Kashi/ A Review and Recommendation of MADM Techniques Application in Real Business, International Symposium of the Analytic Hierarchy

Process 2014, Washington D.C., U.S.A.

evaluation of alternatives becomes more transparent, and clear also for other parties that are more or less engaged in the decision making process. Following table 1 provides a summary of overall characteristics and properties of individual methods from various perspectives.

Table 1

Summary of applications of selected MADM methods

\begin{tabular}{|c|c|c|c|c|c|c|}
\hline \multicolumn{7}{|c|}{ Selection of alternatives / allocation of priorities or ranking } \\
\hline & $\begin{array}{l}\text { No. of } \\
\text { criteria }\end{array}$ & $\begin{array}{l}\text { Selection of } \\
\text { the best } \\
\text { alternative }\end{array}$ & $\begin{array}{l}\text { Evaluation } \\
\text { of } \\
\text { alternatives }\end{array}$ & $\begin{array}{c}\text { Benefit- } \\
\text { cost } \\
\text { perspective }\end{array}$ & $\begin{array}{l}\text { Allocation } \\
\text { of weights } \\
\text { and } \\
\text { priorities }\end{array}$ & Ranking \\
\hline \multirow[t]{2}{*}{$\begin{array}{c}\text { Decision } \\
\text { making }\end{array}$} & $\max 7$ & $\begin{array}{l}\text { AHP/ANP, } \\
\text { DEMATEL }\end{array}$ & $\begin{array}{l}\text { AHP/ANP, } \\
\text { DEMATEL }\end{array}$ & $\begin{array}{c}\text { AHP/ANP, } \\
\text { TOPSIS, } \\
\text { VIKOR }\end{array}$ & $\begin{array}{l}\text { AHP/ANP, } \\
\text { DEMATEL }\end{array}$ & $\begin{array}{c}\text { AHP/ANP, } \\
\text { TOPSIS, } \\
\text { VIKOR }\end{array}$ \\
\hline & $\begin{array}{l}\text { More } \\
\text { than } 7\end{array}$ & $\begin{array}{l}\text { TOPSIS, } \\
\text { VIKOR }\end{array}$ & $\begin{array}{c}\text { DEMATEL, } \\
\text { TOPSIS, } \\
\text { VIKOR }\end{array}$ & $\begin{array}{l}\text { TOPSIS, } \\
\text { VIKOR }\end{array}$ & $\begin{array}{c}\text { AHP, } \\
\text { DEMATEL }\end{array}$ & $\begin{array}{l}\text { TOPSIS, } \\
\text { VIKOR }\end{array}$ \\
\hline Prediction & $\begin{array}{l}\max 7 \\
\text { More } \\
\text { than } 7\end{array}$ & $\begin{array}{l}\text { AHP/ANP } \\
\text { TOPSIS, } \\
\text { VIKOR }\end{array}$ & $\begin{array}{l}\text { AHP/ANP } \\
\text { TOPSIS, } \\
\text { VIKOR }\end{array}$ & $\begin{array}{c}\text { AHP/ANP } \\
\text { AHP }\end{array}$ & $\begin{array}{c}\text { AHP/ANP } \\
\text { AHP }\end{array}$ & $\begin{array}{c}\text { AHP/ANP, } \\
\text { TOPSIS, } \\
\text { VIKOR }\end{array}$ \\
\hline \multirow{2}{*}{$\begin{array}{l}\text { Selection of } \\
\text { strategic } \\
\text { alternatives }\end{array}$} & $\max 7$ & $\begin{array}{l}\text { AHP/ANP, } \\
\text { DEMATEL }\end{array}$ & $\begin{array}{l}\text { AHP/ANP, } \\
\text { DEMATEL }\end{array}$ & AHP/ANP & $\begin{array}{l}\text { AHP/ANP, } \\
\text { DEMATEL }\end{array}$ & $\mathrm{AHP} / \mathrm{ANP}$ \\
\hline & $\begin{array}{l}\text { More } \\
\text { than } 7\end{array}$ & $\begin{array}{l}\text { TOPSIS, } \\
\text { VIKOR }\end{array}$ & $\begin{array}{l}\text { TOPSIS, } \\
\text { VIKOR }\end{array}$ & AHP & $\begin{array}{c}\text { AHP, } \\
\text { DEMATEL }\end{array}$ & $\begin{array}{l}\text { TOPSIS, } \\
\text { VIKOR }\end{array}$ \\
\hline \multirow[t]{2}{*}{$\begin{array}{c}\text { Alternative } \\
\text { development }\end{array}$} & $\max 7$ & $\begin{array}{l}\text { AHP/ANP, } \\
\text { DEMATEL }\end{array}$ & $\begin{array}{l}\text { AHP/ANP, } \\
\text { DEMATEL }\end{array}$ & AHP/ANP & $\begin{array}{l}\text { AHP/ANP, } \\
\text { DEMATEL }\end{array}$ & AHP/ANP \\
\hline & $\begin{array}{l}\text { More } \\
\text { than } 7\end{array}$ & $\begin{array}{l}\text { TOPSIS, } \\
\text { VIKOR }\end{array}$ & $\begin{array}{l}\text { TOPSIS, } \\
\text { VIKOR }\end{array}$ & AHP & $\begin{array}{c}\text { AHP, } \\
\text { DEMATEL }\end{array}$ & $\begin{array}{l}\text { TOPSIS, } \\
\text { VIKOR }\end{array}$ \\
\hline
\end{tabular}

Other applications of MADM methods (in personnel management, finance, strategic management, etc.) provide us with conclusion that it is useful in practice; nevertheless, it is still not widely used technique by business enterprise.

\section{Key References}

Hwang, C.L., Yoon, K. (1981). Multiple attribute decision making, methods and applications. Lecture Notes in Economics and Mathematical Systems, vol. 186.

Ishizaka, A., Labib, A. (2011). Review of the main developments in the analytic hierarchy process. Expert Systems with Applications. 38(11), 14336-14345.

Saaty, T. L. (1977). A scaling method for priorities in hierarchical structures. Journal of Mathematical Psychology. Elsevier: Amsterdam, 1977. 15(3):234-281.

Saaty, T., L. (1996) Decision making with dependence and feedback: the analytic network process. 1. Ed. Pittsburgh: RWS Publications.

Tzeng, G. H., Huang, J.J. (2011). Multiple attribute decision making: methods and applications. Boca Raton: CRC Press.

International Symposium of 5 